\title{
Women on the Path of the Goddess: Sacred Technologies of the Everyday
}

\author{
By Åsa Trulsson
}

\begin{abstract}
Contemporary spiritualties are often portrayed as a turn to a subjective and individualized form of religion, consisting of individually held truth claims or private peak experiences that are generated sporadically at retreats and workshops. The portrayal is ultimately related to a perception of everyday life in contemporary Euro-America as mundane, rationalized, and secular, but also the exclusion of practices centered on the body, the home and the everyday from what is deemed properly religious. This article explores the sacred technologies of the everyday among women in England who identify as Goddess worshippers. The purpose is to further the understanding of religion and the everyday, as well as the conceptualization of contemporary Goddess-worship as lived religion. Through examining narratives on the intersection between religion and everyday activities, the technologies of imbuing everyday life with a sacred dimension become visible. The sacred technologies imply skills that enable both imagining and relating to the sacred. The women consciously and diligently work to cultivate skills that would allow them to sense and make sense of the sacred, in other words, to foster a sense of withness through the means of a host of practices. I argue that the women actively endeavor to establish an everyday world that is experienced as inherently different from the secular and religious fields in their surroundings; hence it is not from disenchantment or an endeavor with no social consequences. The women's everyday is indeed infused with different strategies where the body, different practices, and material objects are central in cultivating a specific religious disposition that ultimately will change the way the women engage with and orient themselves in the world.
\end{abstract}

Keywords: Lived religion, everyday, body, practice, gender, goddess spirituality.

Trulsson, Åsa: "Women on the Path of the Goddess: Sacred Technologies of the Everyday", Culture Unbound, Volume 12, Issue 2, 2020: 293-310. Published by Linköping University Electronic Press: http://www.cultureunbound.ep.liu.se 


\section{Introduction}

One night, Emma woke up with an intense sensation that her spine was moving independently like a snake. ${ }^{1}$ Although she had been taking some meditation classes and reading some books on spirituality, it was this bodily experience which convinced her that there was more to the world than meets the eye: "There is something else, and it is happening. It is not a concept; it happens in the body." The perceived authenticity and profoundness of the experience prompted Emma to change her mode of living by making spirituality the center of her life. The purpose of her endeavors, says Emma, is to create a larger sacred sphere where there is flow, connection, and transformation. To be in contact with this sphere and expand its boundaries are the means and ends of her spirituality. However, living a spiritual life is not easy, according to Emma, but rather associated with considerable effort. Spirituality is, in her view, synonymous with dedicated work on the self, which involves a continuous assessment of feelings, dreams, and experiences in order to establish their spiritual meaning and ensure spiritual growth. It also includes being confronted with aspects that are less than flattering and not particularly pleasurable. Consequently, Emma's preferred choice of word for spiritual practice is work.

Robert Orsi states that "the imaginations of moderns are trained towards sacred absence" and hence not accustomed to acknowledging or feeling a sacred presence in their daily lives (Orsi 2005: 12). Similarly, Julian Holloway argues that the everyday in contemporary Europe is often constructed as quotidian, secularized, and utterly profane, characterized by the processes of rationalization and disenchantment. The sacred, on the other hand, is usually set apart as extraordinary and specific, such as officially recognized events and places (Holloway 2003). Emma's everyday certainly seems to be dominated by a secularized and disenchanted paradigm, but on the other hand, she is determined to discern and create sacred presence until it encompasses her daily life. She is not alone. During my fieldwork among women who identify as Goddess-worshippers, I encountered several women who put great efforts into leading an everyday spiritual life in the face of sustenance, bills, and other daily concerns. In the following, I explore the strategies of these women as they strive to infuse the mundane with sacred qualities. Through examining narratives on the intersection between the everyday and religion, or so-called "sacred stories" (Ammerman 2013), the sacred technologies of the everyday become visible. Sacred technologies is used with reference to Michel Foucault's seminal technologies of the self, and hence suggest a desired state to attain and the techniques available to the subject to do so. According to Foucault, technologies of the self: 
... permit individuals to effect by their own means or by the help of others a certain number of operations on their own bodies and souls, thoughts, conduct and a way of being as to transform themselves in order to attain a certain state of happiness, purity, wisdom, perfection, or immortality. (Foucault 1988:8)

Such technologies are not merely principles but constant endeavors, which both come to constitute the self and open new for new fields of experiences (Foucault 1988). This focus will allow us to both further the understanding of religion and the everyday, as well as the conceptualization of contemporary Goddess-worship as lived religion.

\section{Preliminaries 1: Goddess Worshippers in England}

The Goddess movement could best be envisaged as a loose and amorphous milieu. Participants often shun the term religion, which they associate with male domination, dogma, and inauthentic spiritual expressions. Further, people hold different and often multiple religious identities and tend to move between different religious or spiritual groups (see Trulsson 2010). While extremely heterogeneous in beliefs and practices, different groups and individuals are held together by a focus on female deities, the earth as being sacred, as well as a focus on the body and bodily processes marked as female and sacred. Another common practice is to search for inspirational images and models in prehistory or so-called vernacular religious traditions, as well as indigenous religions. Many Goddess-worshippers use the terms reclaim and re-member to indicate processes of re-interpreting images, symbols, and text to fit into a more Goddess-oriented ethical framework, or, in their own view, strip away layers of patriarchal thinking and retrieve the true meaning of a practice, image, or symbol. Several scholars have critiqued these practices as either a romanticized search for essence or oriental practices that mask colonial and postcolonial structures of power (Klassen 2004, Magliocco 2005, Maya 2019)

The search for the sacred feminine has a long intellectual trajectory, but the Goddess movement in its current form emerged in the 1970s and 1980s when a surge of religious and ritual creativity encountered the peace movement, the women's movement, and the environmental movement. There has historically been quite a radical leaning in the Goddess movement, given its association with these different social movements. This inclination persists, although it would be too much to argue that all participants come to the movement due to political convictions. Some commentators have also indicated the increased commercialization of the movement as a more recent trend, thus undermining 
the countercultural potential (Folz 2006, Bowman 2009, Maya 2019). The Goddess milieu shares affinities with the broader Pagan and occult movement when it comes to historical development, ritual forms, and organizations. This is particularly visible in Great Britain, home of some of the most influential pagan and occult creators of the twentieth century; among them Aleister Crowley and Gerald Gardner (Ferraro 2015).

Given the heterogeneous character of the movement, it is difficult to estimate numbers and draw cohesive conclusions about demographics. The vast majority of participants in the Goddess-oriented fields I participated in were women, although men and other genders have been present at some gatherings. Rather than being a young movement, many participants seem to have been born in the fifties and sixties, although there are also younger participants as well as some older. With notable exceptions, the participants could also be characterized as white and, if not living in Britain, most are from the USA or western parts of Europe. This picture matches the findings of other scholars (e.g. Eller 1993, Orion 1995, Magliocco 2005, Maya 2019). However, socioeconomic backgrounds seem to be more complex. As Matthew Wood argues, researchers of contemporary spirituality have readily assumed a middle-class status to their informants. However, Wood's ethnographic material exhibited status ambiguity on the part of the participants, usually visible in remarks about work and position, which indicated a lack of authority. Upon closer scrutiny, Wood concludes that most of his informants, although educated, could be referred to as the professionalized working class. According to Wood, the relocation of managerial work outside of Euro-America should not be seen as an expansion of the middle class, but rather a capitalist restructuring and the proliferation of so-called white-collar workers involved in administration, clerical, and management occupations (Wood 2007). The participants in my study are similarly, on the whole, quite highly educated, usually with a college degree. As with Wood's informants, they work in administration, clerical, and management occupations. There is also a preponderance of artists, musicians, and self-employed specialists of various kinds, which is a feature that has also been noted by previous research. Hence, the economic status of the participants seems to transcend usual class distinctions (cf. Prince \& Riches 2000, Magliocco 2005)

\section{Preliminaries 2: The Everyday and Religion}

My field sites included different gatherings such as festivals, workshops, seasonal celebrations, classes, regular meetings held by more established groups, women's circles, so-called moon lodges and instances of celebrating the menstrual cycle. Many of the women I encountered participated in several such events, but also 
engaged in the practices of other groups, such as the Goddess Conference in Glastonbury, different Pagan traditions, performed regular Hindu-inspired fire rituals or felt moved by, for instance, Norse or Native American imagery. Most often, they did not hold a particular religious identity and described themselves as spiritual rather than religious. Such positioning, the weak affiliation, and eclectic tendency seem to collude with much of the conceptualization of contemporary spiritualties. These features have in fact been put at the center of conceptualizations about the broader shift in the Euro-American religious landscape and the decline of institutional religion and religious authority in relation to the advance of subjective or self-directed spirituality (e.g. Bellah 1985, Heelas 1996, Heelas \& Woodhead 2005). In this paradigm, spirituality emerges as an analytical concept parallel to the secular and the religious. As stated by Wood, the people concerned are seen as seekers rather than having a clear religious identity, making idiosyncratic journeys through the movement or shopping around at the marketplace-all according to the exercise of self-authority that is taken to be characteristic of spirituality (Wood 2007). Moreover, as spirituality is thought to be located in the private or individual, it seems to be a form of religion that ultimately strengthens the idea of the everyday as mundane and secularized (Fedele \& Knibbe 2013).

However, there is also a growing body of research pointing to the fact that spiritual practitioners themselves use the concept of spirituality to strategically separate a desirable form of religiosity, linked with personal experiences and individuality, from another type of religiosity, connected with dogma, coercion, and institutionalization. Here, scholars argue that there is a tendency in previous research to accept this normative distinction as an analytical description of contemporary spirituality, a tendency that was strengthened because it also seems to fit with the broader theoretical perspectives of cultural and religious change (Wood 2007, Zwissler 2007, Trulsson 2010, Fedele \& Knibbe 2013). In the present article, the term spiritual is not meant to imply a distinction from religion, neither as something less dogmatic nor as something more self-centered. The term is kept partly out of convenience, but also because such self-descriptions and strategic positionings are interesting aspects of contemporary religious life in itself (cf. Aune 2014). Further, in line with several scholars, I argue that contemporary spirituality is better theorized as lived religion (cf. Aune 2014, Fedele 2015). According to Meredith McGuire, such an understanding of religion prioritizes the actual experiences, practices, and beliefs of the religious person rather than the prescribed religion of institutions and religious authorities. Lived religion includes practices that center around the body, the home, and the everyday, which often have been excluded from what is considered proper religion by scholars and religious authorities alike (McGuire 2008). Hence, there is a shift in focus from adherence to doctrines or practices to how religious practitioners actually relate 
to what they hold sacred in their everyday lives (Ammerman 2013, see also Orsi 2005).

Moreover, as noted by Marja-Liisa Keinänen, the religious lives of women have often been associated with the home and the everyday rather than institutional settings, and have consequently been deemed as not really religious (Keinänen 2010a). This tendency might also have a bearing on the conceptualization of contemporary spirituality as something other than religion, both because of the great numbers of female practitioners and its non-institutional character. However, an analysis of contemporary spirituality with its amorphous character could contribute to a theoretical shift in the understanding of religion (cf. Griffin \& Clifton 2004, Gemzöe \& Keinänen 2016). Today, there are several studies of contemporary spirituality, which put practice, the body, and materiality at its core (e.g. Pike 2001, Salomonsen 2002, Trulsson 2010, Fedele 2013, Utriainen 2016). Yet, with notable exceptions, many of these ethnographies tend to focus on specific events, such as pilgrimages, workshops, and festivals. These events give great importance to intensity and affect, but are also temporary, which means that participants leave and might never return. This does not mean that such activities are inconsequential, but we also need to pay attention to how they are contextualized in the everyday lives of the women.

\section{Fieldwork among Goddess Worshippers}

Between the year 2000 and 2008, I visited and participated in several women-only groups, as well as festivals, workshops, and courses with mixed participants. As the other participants moved between different groups and often traveled great distances to take a particular class or participate in an event, I decided to do likewise. I hence came to follow the rhythm of the participants instead of focusing on a specific site. My fieldwork became concentrated in England, but I also visited other groups and gatherings in Italy, Germany, and the Netherlands. I soon discovered that the same people tended to show up at different events, hence forming a network and allowing me to follow some of them more closely over several years. I frequently visited several of the women in their homes and socialized informally with them over prolonged periods. I also complemented participant observation with more formal interviews with women who were variously engaged in the different groups in terms of status and length of participation. It should be noted that women who quite rapidly drifted out of practice or did not return at all, were not included in this sample. The actual number of these participants vis-à-vis those who returned is uncertain and furthermore difficult to obtain. There is no definite line between claiming to attend a workshop, for instance, in order to "recharge the batteries" and to gain "learning tools and find out more about myself." 
As stated by Anna Lund, ethnography and interviewing tend to blend into each other, as ethnography entails conversation, and researchers often make observations during interviews (Lund 2019). Moreover, interviews during my fieldwork could revolve around cherished objects as well as the participants showing me around significant parts of their home or neighborhoods. Most often, participants framed their thoughts and experiences as stories both in conversation and in formal interviews (cf. Riessman 2008). These stories are reminiscent of Ammerman's concept of sacred stories, that is, narratives on the intersection of religion and the everyday. Ammerman argues:

Looking for religion in narratives and practices, we gain a new perspective that allows us to see how spiritual resources are generated, nurtured and deployed across the many religious and secular contexts in which people live their lives. (Ammerman 2013: 7)

It is important to note that such stories do not give us immediate access to experience, but rather involve inexact representations or reflections thereof. The women reflect on their experiences, which hence are objectified, and in some sense edited in relation to the here and now (e.g. Riessman 2008, Ammerman 2013). They could be crafted to prove a specific point or present a desired course of action. Hence, the stories could themselves be seen as part of the diligent work in interpreting experiences and events within a spiritual framework. Further, as I analyze the stories of the women, I create another story in relation to the objectives of my study. In order to retain the women's voices as much as possible, the main arguments are illustrated with the stories of three specific women. Even though they cannot be seen as representatives of the Goddess worshippers, their stories highlight something essential in the process of the sanctification of the everyday. Stories are never entirely personal but relate to larger dominating narratives that penetrate the lives of the women concerned (cf. Plummer 1995, Riessman 2008, Ammerman 2013).

\section{Sarah: Sensing and Making Sense of the Sacred}

Sarah is in her fifties and works as an office clerk in a large city in England. I met her at several Goddess-oriented retreats and workshops, in which she participated as often as she could. Sarah once told me about an experience during a trip to Crete. She and her friend had been looking for a specific cave for hours in the heat. When they finally arrived, they were exhausted, but the cave was, according to Sarah, amazing. The women decided to perform a ceremony there and call in the Goddess. Sarah started reciting The Charge of the Goddess, which is a well-known 
invocation widely used in Pagan and esoteric milieus. As she used to chant it daily and hence knew it by heart, it seemed like an appropriate thing to do. This time was, however, different. Sara claims that she felt as if the divine was speaking through her:

I opened my mouth and started, and...that was not just me. You know when I talked about coming from here [touching belly]. This was like swoosh! And I was like, what the fuck, I've gotta keep up with this.

Sarah describes her experience as a qualitative shift in somatic sensations: a swirling through the stomach and an alteration of the speed and tone of her voice. Naturally, the very stipulation of the existence of the sacred is a prerequisite for recognizing and marking such sensations as religious experiences (cf. Rappaport 1999). Sarah's experience also unfolds in a ritual setting, which is created by two women with knowledge and skills in these matters. Moreover, in Sarah's narrative, just as with Emma's narrative quoted at the beginning of the article, the framing of the experience as primarily bodily sensations lends a certain authenticity to it. The sacred is not a concept or intellectual statement anymore, but something that can be heard and felt. Over the years, Sarah claims to have learned how to recognize the sacred in a more sustained manner. Although not as dramatic as the experience in Crete, she still presents the presence of the sacred as sensed in the body. She says: "So it's very much sensed in some way, and it's like some days I just feel that I get this feeling that there is a bigger picture going on all the time and I get glimpses of it."

As stated before, Sarah regularly partakes in several courses and workshops. She is also training to become a Priestess of Avalon, which is a three-year-long devotional training involving specific ritual and religious practices connected to the Goddess community in Glastonbury. Sarah claims that the main reason for entering the training was to connect with "women in their power", but also to "work with the Feminine." Hence, the course provides her both with the possibility to relate to other women, whom in Sarah's view embody a desired state of being in their power, and specific tools that are viable forms for relating to the nominally sacred, that is the Feminine. It could be acts, such as movements to establish sacred space, invocations or chants, specific modes of smudging the room or oneself, or different techniques of meditation and guided visualizations, or it could be objects, such as statues, drawings, or specific mementos used during ceremonies. Most importantly, during this and other courses, Sarah is invited to explore personal experiences and meaning in relation to the teachings, techniques and practices featured. "Working with the Feminine" hence means to explore 
and relate different practices and experiences to the sacred entities featured in the course, but also to female subjectivity and individual meaning-making. The training thus provides Sarah with a sense of the sacred, but also the tools to make sense of the sacred, i.e., the skills to interpret certain experiences as sacred and essential to her sense of self.

Today, Sarah has established a daily routine in which she uses these learned practices as a repertoire to relate to the sacred, for instance, reciting The Charge of the Goddess. In fact, according to her, such practices are central parts of bringing about a sense of the sacred. She says, "hopefully with every time I connect more deeply with that [the sacred], really be connected and aware." By regular and diligent practice, Sarah hopes to access moments where the presence of the sacred is felt in the body but also extend that presence until it unfolds daily life in its entirety. She argues:

Spirit is here now, it's not something over there and something we are going to obtain, it's here. It's just a case of us learning to recognize it. I was actually earlier going that it is this peak experience, whereas I am very aware that it's just that being.

The anthropologist Thomas Csordas might call Sarah's description a sense of withness, which means that the self has access to the realm of the sacred at given times but also senses the presence of the sacred in any situation. Meaning is here not to be understood in semantic terms, but includes "a modulation of being in the world [...] a different sensibility about oneself as a culturally defined person" (Csordas 1994: 171). Such modulation can also mean that other tasks can be performed in a spiritual manner. Sarah says:

I always used to say I was getting sort of a spiritual practice of washing up. Because just being there. A sort of practicing really, feeling things and watching the sort of...even just the little aspects of shadows and things like that. It sounds really; I don't know. . .basic.

Hence, even mundane chores, such as cleaning and washing up, could be part of a spiritual regime. Such activities are traditionally excluded from the religious sphere, which also Sarah seem to be well aware of. Such perceptions mark her presentation of spiritual practice as basic.

\section{Eva: Practicing the Sacred}

Eva is in her forties, just broke up with her partner, and moved to the English countryside. In her spare time, she participates in workshops in the Goddess 
milieu, and she volunteers at a local Goddess temple. For Eva, it is essential to be connected and grounded. She repeatedly chooses these expressions instead of speaking about specific doctrines or Goddesses. In fact, most women I met during fieldwork also seemed to favor these expressions for implying a kind of relationship to the sacred to which they aspired. The words grounded, connected, and the equally common presence are all hard-to-define in terms of their semantic content. Moreover, these words could mean different things to different women, and their meaning could shift over time. Most often, such words were not explained at all, but rather taken for granted as expressions for desired spiritual states. The vagueness of these expressions protects them from intellectual scrutiny (cf. Luhrmann 1989) but simultaneously gives them the possibility to cater for a wide range of individual experiences. Moreover, the extent of their usage and their taken-for-granted character imply that these expressions are widely shared in verbal interaction. They have gradually become established as appropriate expressions for what it means to lead a spiritual life. Yet, the phrases are also suggestive of corporeal states. They could be likened to a sense of withness in that the self is set in relation to a specific cultural construction of the sacred but also has the ability to access sacred reality at any time. Eva states:

When I speak of connection, for example, connection is also feeling and embodying love, and of course, that is not possible all the time. [...] But when you realize that you are imbalanced you know a way to bring yourself back into that place gently.

Eva states that rituals make her connect more easily and deeply, but also allow her to keep this connection in other parts of her life. She engages in a host of different forms of practices, such as walking the land, lighting candles, smudging, or just sitting in front of her altar, on a daily basis. They are simple acts of the everyday, but Eva presents them as the means to realize the desired state itself: to be connected. Furthermore, she also argues that repeated practice makes it easier to do so:

I think also where you have your little altar, no matter how big or small it is. Also, with the rituals or something that you make your sacred space and that I believe that already by sitting there, you can tune in easily and are quickly connected as well.

The acts are both the means of realizing a sense of withness and the means of training the body to recognize it. Eva associates her daily spiritual practice, although joyous, with discipline. One has to make an effort to get up in the 
morning, sit in front of the altar or walk the land, and moreover to do so on a regular basis. As Eva says: "Because you stick to it [...] and it becomes a habit." However, a habit for Eva does not mean mechanical execution of other people's rules, but the possibility of practicing almost without thinking or, in her own words, without forcing herself: "It's just time for prayer, and it's then easier to tune in quicker and ground yourself." The goal is to be connected without effort, yet the means of realizing this is through diligent and repeated practice. Moreover, through sustained daily practice, a particular routine is created that becomes a constant reminder of the presence of the sacred in the individual's life and creates a certain temporality and comportment during the day. Repeatedly rising before daybreak to meditate or walking the land after work is finished, in short, making space for spiritual practice, affects the rest of the day in that it is structured accordingly. Such routines thus have the potential to include everyday practices in their entirety, which is also Eva's intention.

\section{Martha: Surrounded by Goddess}

Martha is in her fifties and works as a web designer. Stepping into her living room is like stepping into a sacred space. There are candles, goddess figurines, and spiritual artwork everywhere. Most of the objects are not used in any religious practice but mingle with more commonplace objects like coasters, flowers, and photographs of family and friends. Martha says:

I like to celebrate Goddess. The whole house is sort of full of her, everywhere you look... Goddesses everywhere. It's just my whole life is surrounded by Her. [...] I don't feel the need to have specific celebrations very often. It is just enough for me to be surrounded.

To be surrounded by the different Goddesses allows Martha to relate to different activities in a sacred way. She says that she writes and constructs websites in an almost ceremonial manner, without implying that she has to engage in any ritual techniques. Although Martha is a trained priestess, she argues that making elaborate ceremonies is not her primary concern. Sometimes she lights a candle and says a prayer for inspiration, but she would rather create conditions where ceremony is possible - "like the drop of a hat."

Some commentators even claim that contemporary spiritualties are especially aligned with a neo-liberal consumerist ethos (Bruce 2002, Carette \& King 2005, Hornborg 2011) while others argue that consumer goods allow participants to demarcate and display their spiritual identity (Pike 2001, Magliocco 2005, Utriainen 2016). However, I would argue that understanding the decoration as 
solely a matter of communication or aesthetic display would miss important aspects of motivation and the use of these objects. The different goddess figurines might very well be purchased as commodities at one point, but in Martha's case, their usage has changed into being primarily about creating a sense of being surrounded or even a sense of withness. As stated by Arjun Appudarai, the quality of the object is determined by its social context and hence shifting (Appadurai 1986). Martha's desired state allows both access to the realm of the sacred and a possibility to sense the sacred in any situation (cf. Csordas 1994). Hence, obtaining a replica of, let's say, Venus of Willendorf is not only a matter of aesthetic display or even about being reminded of the certain characteristics that the Goddess is thought to embody, but rather the presence of this image effectively transforms routine living arrangements. Moreover, as Martha does not separate her figurines from her mundane dwellings, such as the kitchen, bedroom, or even the toilet, but instead keeps images everywhere as a way to infuse her whole life with sacred connection, the distinction between the sacred and routine spaces is hard to sustain. The home becomes an important religious arena in parallel with designated public spaces of worship (cf. Keinänen 2010b). Moreover, her rooms are often filled with the fragrance of incense and the recorded sounds of chants or Goddess-oriented songs. As argued by Csordas with regards to the Charismatics, even though such music forms a background to perfectly mundane activities, such as vacuuming or washing the dishes, themes of ritual reality come to extend to everyday reality, imbuing it with specific sacred characteristics (Csordas 1997).

Martha argues that she gets a sense of withness out of nowhere, sitting in her garden, walking around in the countryside or driving her car. "You know it can come anywhere, anytime." Of course, the statues are not the only means to realizing this. Except for simple acts of devotion and prayer, Martha lifts the importance of staying honest in her convictions in any situation

And so if we are as brave as we can be and as honest as we can be and we talk about Goddess, out there, where it is not really, you know ... in the town central, at the bus stop, to the old lady that disapproves...

Martha's spirituality is hence not confined to the private sphere or the limits of her home. Being open about her conviction and also acting spiritually in public is a mode of infusing the everyday with sacred qualities. For Martha to engage in a spiritual path would mean trying to change the world in its entirety; the efforts do not stop until another kind of world is realized:

Until we can contain it in a different sort of container. One that is more friendly towards women, more peaceful. And to me that includes no 
wars, no starvation, no destroying the earth and letting people just be. [...] It's really about completely altering the way the world works. You see, I don't want much [laughter], just everything.

It is vital to remember that Martha does not relate this at all to a planetary shift or the intervention of the divine, but rather to hard work and changing her thinking and living habits. As such, the connection between Martha's spiritual path and her habits of living and consuming could be seen as a strategy to expand a sense of withness until it encompasses her entire life.

\section{Discussion}

The equation between the everyday and the mundane could be viewed as dependent on the very understanding of religion as opposed to the quotidian; activities such as working, child-rearing, preparing food, sleeping, and so on are seen as profane and separated from the sacred. Holloway locates this conceptualization primarily in the influential theories of Eliade, who distinguishes the holy from the profane in the form of eruptions or hierophanies (Holloway 2003, see also Eliade 1959). However, as argued by McGuire, such conceptualizations are ultimately built on historical processes and discursive strategies that aim to distinguish between true religion and magic, idolatry or superstition, as well as between religious elites and laypeople. It thus excludes practices and beliefs that might be very important in people's lives, such as practices centered on the body or the everyday, as not properly religious (McGuire 2008). In such conceptualizations, the emergence of different forms of spiritualties, such as Goddess worship, becomes labeled as something other than religion, perhaps even denigrated as narcissistic, subjective, and with no social consequence (cf. Sointu \& Woodhead 2008). The introduction of spirituality as an analytical category both underlines and is underlined by such distinctions. However, as pointed out by several scholars of contemporary spirituality, there are affinities between the practices of contemporary spiritualties and religious life outside the confines of learned debates and theological exegesis (Bowman 2009, Trulsson 2010, Aune 2014, Fedele 2015). It hence makes sense to theorize contemporary spiritualties as lived religion. Consequently, research on these situations also needs to pay more considerable attention to the religious lives of the practitioners outside workshops, courses, festivals, and other similar events.

The efforts of people like Emma, Sarah, Eva, and Martha challenge the notion of a complete secularized everyday life, and make the rigid distinctions between the sacred and profane hard to maintain. Although they perceive mainstream structures to be somewhat at odds with their spiritual practices and goals, they also actively strive to transcend such binaries through different means. They 
attempt to create a life where spirituality is not compartmentalized or kept private. The women's narratives are suggestive of a conscious and constant effort to sustain a sense of withness or a specific orientation towards the sacred that influences most activities. For many of the women, it involves a thorough restructuring of everyday life, so that spiritual inclinations inform almost all practices such as earning a living, consumption, decorating living spaces, and other daily activities. It is important to note that the women's spirituality does not preclude collective action, such as rituals, nor does their spirituality suggest an apolitical endeavor with no social consequence. On the contrary, ceremonies, joint gatherings, and even an overt desire to effect social change are central tenets. However, it is also important to remember that a sense of withness is a desired state to attain rather than an absolute condition that penetrates the everyday lives of the women. The stories also show that a dominating narrative of a secular and disenchanted everyday marks the women's perceptions and experiences. The women need to move within spheres where the sacred is not acknowledged, for instance, because of work, healthcare, the educational system, or family and friends (cf. Utriainen 2014). Their efforts unfold in relation also to these secular constructions of the everyday.

In her studies of contemporary angel practices in Finland, Terhi Utriainen points to the importance of learning and cultivating skills in order to be able to both imagine and relate to nominally sacred entities, such as angels. Hence, she argues that much of contemporary spiritualties could be seen as "a non-stable set of enchanting imaginary-practical technologies: an art for crafting lives and futures" (Utriainen 2014: 245). In a similar vein, the sacred technologies described in this article imply skills that enable both imagining and relating to the sacred. Following Foucault's perspective would, however, mean a shift of attention from what such skills represent to what they do in terms of constituting ethical subjects that are recognizable as such to the broader Goddess community. Such practices also open up new fields of experience (cf. Foucault 1988). The women consciously and diligently work to cultivate attitudes and skills that would allow them to sense and make sense of the sacred, in other words, to foster a sense of withness. This is a process that naturally involves entertaining the possibility of the sacred, as well as reflecting on and expressing experiences to others, including myself, during interviews. The women also engage in a host of intentional everyday acts, as well as more formalized ritual acts, to develop habits that would shape their emotions, desires, and motivations, in short their entire mode of relating to the world (cf. Mahmood 2005). Indeed, the women present practices as the primary means for establishing a sacred everyday life (cf. Aune 2014). Still, their narratives also reveal a diligent work on the self in terms of scrutinizing and molding thoughts, behaviors, and principles in relation to their experiences (cf. Foucault 1988). 
All the women present the presence of the sacred as sensed through the body. These could be intense and temporary experiences, but they can also be more sustained sensations of being grounded or connected that have the potential to influence everyday proceedings. The body thus emerges as the locus for the relationship and engagement with the sacred. To continuously sense the sacred requires a modification of the modes of attention-a different orientation in the world, and is hence vital to the spiritual formation of the self. As noted by Eva Souintu and Linda Woodhead, the treatment of the body as "the starting point for exploration of an individual's relationship with her own subjectivity and sacred presence" challenges dominating narratives where women's bodies are objectified and sexualized, or perform unpaid domestic work (Sointu \& Woodhead 2008: 269). However, presenting religious experiences as primarily bodily states is also a strategy that sets them apart and in some sense signals authenticity for the women concerned. A corporeal sensation is something real and set apart from what only happens in the head and is hence possibly fabricated. It reveals that what is sensed and understood in the body is a privileged path to knowledge, which in turn also implies a critique of both the more rationalized processes that are perceived to dominate the everyday and the alleged dogmatic tendencies of other religious traditions. Similarly, the vague idioms that are favored even by the women who are trained priestesses of the Goddess indicate both a critique and a desire to create a religion free from dogma and open to different expressions and forms of the divine. Such positioning, however, does not preclude that these expressions implicate a particular understanding of nor relationship to the world.

In these processes, the home, its decorations, and the activities of daily living, such as cleaning and washing up, become important as sacred technologies. It seems ritual practice for the women is contained within a spectrum of practices that are considered spiritual by their mode of execution, not in the sense that an outside observer might understand them as such, but because of their utter meaningfulness to the performer. Ritual practice is thus only one way of acting spiritually or religiously (cf. Mahmood 2005, Keinänen 2010b). However, even if they are temporary and perhaps distinguished from everyday living through their intensity and seclusion, events such as workshops, courses, festivals, and ritual gatherings are essential to the women. Such events provide tools and techniques that can be further explored at home, as well as an imagery where the body can be used both to access the sacred and work on the self. There is hence a didactic aspect in these gatherings in that participants learn to sense, recognize, and consciously induce withness. It does not mean that the women mindlessly follow the visions of the authorities or leaders. Rather they move between these different events, make use of several different practices depending on moods and needs, and moreover creatively re-negotiate the content to make sense of their own lives and everyday 


\section{Culture Unbound}

Journal of Current Cultural Research

concerns (cf. Trulsson 2010, 2013). Here, the body is not only an actor but also a learner where certain states can be evoked if the individual regularly performs the practice. This is different from suggesting a belief-centered approach, in that knowledge of the sacred or the divine is not primarily transmitted in dogmas or stable representation, but rather experientially through practice.

Åsa Trulsson is a senior lecturer in cultural sociology at the Department of Cultural Sciences, Linnaeus University. She earned her Ph.D. in religious studies, which focused on ritual creativity among contemporary Goddess worshippers. Her more recent research focuses on the intersection of migration, religion, and belonging with a particular emphasis on young people and schooling. E-mail: asa. trulsson@lnu.se

\section{Notes}

1 In order to protect their integrity, all of the names of the research participants are pseudonyms.

\section{References:}

Ammerman, Nancy (2103): Sacred Stories, Spiritual Tribes: Finding Religion in Everyday Life, Oxford: Oxford University Press.

Appadurai, Arjun (1986): The Social Life of Things: Commodities in Cultural Perspective, Cambridge: Cambridge University Press.

Aune, Kristin (2014): "Feminist Spirituality as Lived Religion: How UK Feminists Forge Religio-Spiritual Lives," Gender and Society 29: 1, 122-145, https://doi. org/10.1177/0891243214545681.

Bellah, Robert. (1985): Habits of the Heart: Individualism and Commitment in American Life, Berkeley: University of California Press.

Bowman, Marion (2009): "Learning from Experience: The Value of Analysing Avalon," Religion 39, 161-168, https://doi.org/10.1016/j.religion.2009.01.016.

Bruce, Steve (2002): God is Dead: Secularization in the West, Oxford: Blackwell Publishing.

Carette, Jeremy \& Richard King (2005): Selling Spirituality: The Silent Takeover of Religion, London: Routledge.

Csordas, Thomas (1994): The Sacred Self: A Cultural Phenomenology of Charismatic Healing, Berkeley: University of California Press.

Csordas, Thomas (1997): Language, Charisma and Creativity: The Ritual Life of a Religious Movement, Berkeley: University of California Press.

Eliade, Mircea (1959): The Sacred and the Profane: The Nature of Religion, New York: Routledge.

Eller, Cynthia, (1993): Living in the Lap of the Goddess: The Feminist Spirituality Movement in America, New York: Crossroads.

Fedele, Anna (2015): "Iberian Paganism: Goddess Spirituality in Spain and Portugal and the Quest for Authenticity," Kathryn Roundtree (ed.), Modern Pagan and Native Faith Movements in Europe: Colonial and Nationalist Impulses, Oxford and New York: Berghahn, 239-260.

Fedele, Anna (2013): Looking for Mary Magdalene: Alternative Pilgrimage and Ri- 


\section{Culture Unbound}

Journal of Current Cultural Research

tual Creativity at Catholic Shrines in France, Oxford: Oxford University Press.

Fedele, Anna \& Kim E. Knibbe (2013): "Introduction: Gender and Power in Contemporary Spirituality," Anna Fedele \& Kim E. Knibbe (eds), Gender and Power in Contemporary Spirituality, New York: Routledge, 1-27.

Ferraro, Shai (2015): "Connecting British Wicca with Radical Feminism and Goddess Spirituality during the 1970s and 1980s: The Case Study of Monica Sjöö," Journal of Contemporary Religion 30: 2, 307-321, https://doi.org/10.1080/13537903.201 $\underline{5.1025560}$

Foltz, Tanice (2006): "The Commodification of Witchcraft." Helen Berger (ed.), Witchcraft and Magic: Contemporary North America, Pennsylvania, Pennsylvania University Press, 137-168.

Foucault, Michel (1988): “Technologies of the Self," Luther H. Martin, Huck Gutman \& Patrick H. Hutton (eds), Technologies of the Self: A Seminar with Michel Foucault, Amherst: The University of Massachusetts Press, 16-49.

Gemzöe, Lena \& Marja-Liisa Keinänen (2016): Contemporary Encounters in Gender and Religion: Introduction," Lena Gemzöe, Marja-Liisa Keinänen, \& Avril Maddrell (eds), Contemporary Encounters in Gender and Religion: European Perspectives, Cham: Palgrave McMillan, 1-28.

Griffin, Wendy \& Chas Clifton (2004): "Preface," Jenny Blain, Douglas Ezzy \& Graham Harvey (eds), Researching Paganisms, Oxford: Altamire Press, vii-viii.

Heelas, Paul. (1996): The New Age Movement: The Celebration of Self and the Sacralization of Modernity, Oxford: Blackwell

Heelas, Paul \& Linda Woodhead (2005): The Spiritual Revolution: Why Religion is Giving Way to Spirituality, Malden: Blackwell Publishing.

Holloway, Julian (2003): "Make-believe: Spiritual Practice, Embodiment, and Sacred space," Environment and Planning A 35:11, 1961-1974, https://doi.org/10.1068/ a3586.

Hornborg, Ann-Christine (2011): “Are We all Spiritual?" Journal for the Study of Spirituality 1: 2, 249-268, https://doi.org/10.1558/jss.v1i2.249.

Keinänen, Marja-Liisa (2010a): "Introduction," Marja-Liisa Keinänen (ed.), Perspectives on Women's Everyday Religion, Stockholm: Acta Universitatis Stockholmiensis, 9-37.

Keinänen, Marja-Liisa (2010b): "The Home, the Sacred Order and Domestic Chores in Premodern Russian Orthodox Karelia," Marja-Liisa Keinänen (ed.), Perspectives on Women's Everyday Religion, Stockholm: Acta Universitatis Stockholmiensis, 119-153.

Klassen, Chris (2004): "The colonial mythology of feminist witchcraft", The Pomegranate $6.1,70-85$.

Lund, Anna (2019): “'I feel sorry for them and I should do something, but I don't': Spatial imaginaries and resistance to feminist change in the dramatic arts," Emotion, Space and Society 30, 27-33, https://doi.org/10.1016/j.emospa.2018.12.003

Luhrmann, Tanya (1989): Persuasions of the Witch's Craft: Ritual Magic and Witchcraft in Present-day England, Oxford: Basil Blackwell

Magliocco, Sabina (2005): Witching Culture: Folklore and Neo-Paganism in America, Philadelphia: University of Pennsylvania Press

Mahmood, Saba (2005): Politics of Piety: The Islamic Revival and the Feminist Subject, Princeton: Princeton University Press.

Maya,Kavita(2019): “Arachne's Voice:Race, Genderand the Goddess”, Feminist Theology 28.1, 52-65, https://journals.sagepub.com/doi/10.1177/0966735019859469

McGuire, Meredith (2008): Lived Religion: Faith and Practice in Everyday Life, Oxford: Oxford University Press.

Orion, Loretta (1995): Never Again the Burning Times: Paganism Revived, Illinois: Waveland Press.

Orsi, Robert (2005): The Madonna of 115th Street: Faith and Community in Italian 
Harlem, New Haven: Yale University Press.

Pike, Sara M. (2001): Earthly Bodies, Magical Selves: Contemporary Pagans and the Search for Community, Berkeley: University of California Press.

Plummer, Ken (1995): Telling Sexual Stories: Power, Change, and Social Worlds, London: Routledge.

Prince, Ruth \& David Riches (2000): The New Age in Glastonbury: The Construction of Religions Movements, Oxford: Berghahn

Rappaport, Roy (1999): Ritual and Religion in the Making of Humanity, Cambridge: Cambridge University Press.

Riessman, Catherine Kohler (2008): Narrative Methods for the Human Sciences, Los Angeles: Sage Publications.

Salomonsen, Jone (2002): Enchanted Feminism: Ritual, Gender and Divinity among the Reclaiming Witches of San Francisco, London: Routledge.

Sointu, Eva \& Linda Woodhead (2008): "Spirituality, Gender, and Expressive Selfhood," Journal for the Scientific Study of Religion, 47:2, 259-276, https://doi. org/10.1111/j.1468-5906.2008.00406.x

Trulsson, Àsa (2010): Cultivating the Sacred: Ritual Practice and Creativity among Women in Contemporary Europe, Lund: Mediatryck.

Trulsson, Åsa (2013): "Cultivating the Sacred: Gender, Power and Ritualization in Goddess-oriented groups," Anna Fedele \& Kim Knibbe (eds), Gender and Power in Contemporary Spirituality: Ethnographic Approaches, New York: Routledge, $28-45$.

Utriainen, Terhi (2014): "Doing Things with Angels: Agency, Alterity and Practices of Enchantment," Steven Sutcliffe \& Ingvild Saelid Gilhus (eds), New Age Spirituality: Rethinking Religion, New York: Routledge, 242-255.

Utriainen, Terhi (2016): "Desire for Enchanted Bodies: The Case of Women Engaging in Angel Spirituality," Lena Gemzöe, Marja-Lissa Keinänen, \& Avril Maddrell (eds), Contemporary Encounters in Gender and Religion: European Perspectives, Cham: Palgrave McMillan, 175-193.

Wood, Matthew (2007): Possession, Power and the New Age: Ambiguities of Authority in Neoliberal Societies, Aldershot: Ashgate.

Zwissler, Laurel (2007): "Spiritual but not Religious: 'Spirituality' among Religiously Motivated Feminist Activists," Culture and Religion 8:1, 51-69, https://doi. org/10.1080/14755610601157120. 